\title{
Risk Preference Changes in the Kuwait Banking System's Effect on Profitability
}

\author{
Joseph Trendowski \\ Valparaiso University \\ Elzotbek Rustambekov \\ Bryant University \\ Jassem Al Shamaa \\ Burgan Bank \\ Abdullah Alonazi \\ Valparaiso University
}

\begin{abstract}
As the institutional structure of the Kuwaiti banking market shifts, institutions are adopting a more westernized approach. Traditionally, the banking system followed closely with Sharia Law, similar to countries like Saudi Arabia. Recently, Kuwait has implemented legal changes that have allowed banks the ability to increase risk taking. Additionally, outside investment is being encouraged, resulting in Kuwait now being considered an emerging market. This paper examines the impact on Kuwaiti bank profitability resulting from increased risk taking.
\end{abstract}

\section{INTRODUCTION}

Traditionally, business practices in western countries were vastly different than those operating in the Middle East (Kuran, 2012; Metcalfe, 2006, 2007). However, over time, some countries like Kuwait are engaging in a mixed system that combines Islamic principles with nuances of the Western approach (AlKulaib, Al-Jassar, \& Al-Saad, 2016; Velez-Calle, Robledo-Ardila, \& Rodriguez-Rios, 2015). Bankers often find the western system more attractive as it often provides greater profitability (Abedifar, Ebrahim, Molyneux, \& Tarazi, 2015; Iqbal \& Molyneux, 2016). One key difference is the interest factor: though many western banks rely on interest as a source of income, many scholars of Sharia Law dismiss it because interest is prohibited in the religion of Islam (Chong \& Liu, 2009; Saeed, 1996). Sharia means a path or a way. In Islam, Sharia refers to the divine guidance and laws were given by the Holy Quran, the Hadith (sayings) of the Prophet Muhammad (Sallallahu Alaihi Wassalam) and supplemented by the juristic interpretations by Islamic scholars. Sharia exemplifies all parts of the Islamic faith, including beliefs and practices. Sharia-compliant finance is a type of financing activity that meets the terms of sharia (Islamic law). Sharia forbids riba which is defined as interest paid on the loans (Coulson, 2017). 
Additionally, Islamic banks do not charge ATM fees, overdraft fees, or interest, but rather charge a $\$ 100$ fee for a credit card issue (Abdul-Muhmin \& Umar, 2007; Ali, Raza, \& Puah, 2017). In these countries, banking is primarily relationship-based, extending beyond the customer service of western banks. For instance, it is common for Middle Eastern bankers to make visits to the customer's home to conduct business. Adding to the strong relationship, banks often meet semi-annually with client groups to share ideas and improve service (Makki \& Chang, 2015).

Comparatively, western cultures, such as the United States, have a much different approach. The United States has a long history of providing opportunity for profitability. Throughout the last $150+$ years, the U.S. banking sector has undergone several boom and bust cycles, ultimately leading to regulatory changes. Bank risk can often lead to higher profitability, but may also lead to higher failure rates (Trendowski \& Rustambekov, 2017), though the temptation for greater profits often dispels many fears (Cooper \& Jarre, 2017). The Federal Reserve was created in 1913 to dispel fears and return consumer confidence after banking crises in 1873, 1884, 1890, 1893, and 1907 (Bruener \& Carr, 2007). Since its inception, there have only been three large scale crises in the century that followed $(1930 \mathrm{~s}, 1980 \mathrm{~s}$, and 2008). The Federal Deposit Insurance Corporation (FDIC) was established in 1933 to safeguard deposits as part of the Banking Act of 1933 (Also known as the Glass-Steagall Act) and tightened regulation regarding how banks were run.

\section{ISLAMIC BANKING}

With the spread of Islam, the teachings of the Quran and the Sunnah introduced a new financial system that provides all citizens free of interest (riba) banking and introduced equal rights for all. In commencing businesses and transactions, various communities in the Middle Eastern region used Sharia Law, so they prospered and expanded into an immense trading arena. In the modern world, the Islamic banking system has established itself across the world and recognized as a major banking system in both western and eastern societies around the world.

The primary function of Islamic banking often goes beyond profitability (Schotter \& Abdelzaher, 2013). Islamic banking is defined by the Organization of Islamic Conference (OIC) as: "A financial institution whose rules and procedures state its commitment according to
the principles of Islamic Sharia and banning of interest on any of its operations".

The fundamental system of Islamic banking is often traced to Ahmad El-Najjar of Egypt in the middle of the twentieth century. During the 1950s, Muslim scholars developed a banking system based on the fundamental principles of Islam: a system free of interest. In 1980, the Islamic Training Instutute developed by the Islamic Development Bank fostered continued growth in this area. Expansion of Islamic banking would continue into the 1990s as governments and lawmakers became more interested in this system (Beck, Demirgüç-Kunt, \& Merrouche, 2013). Additional products and services were introduced, such as Islamic insurance and Islamic equity funds. This financial system provides citizens, free of interest (Riba), a banking system aligning with Sharia Law. Today, Islamic banking is well established and highly recognized as a major banking system in both western and eastern societies (Beck, et al., 2013).

\section{TRADITIONAL ISLAMIC BANKING IN SAUDI ARABIA}

Whereas Kuwait is shifting towards a more mixed model of banking, Saudi Arabia maintains its traditional Islamic banking structure (Al-Malkawi, Mansumitrchai, \& Al-Habib, 2016). Islamic Law is meant to be all-embracing; therefore all legislation is meant to supplement Islamic Law (Coulson, 2017). The government may issue regulations, but must strictly follow Islamic teaching (Coulson, 2017). Any alteration that conflicts with established principles of Islamic Law is not allowed. There are numerous areas of law where Islamic Law offers few or no guidelines, and where government-made legislation is, 
therefore, the only law (Coulson, 2017). If there is a conflict between the regulations and Islamic Law, such regulations would be void to the extent of the conflict.

\section{TABLE 1}

\section{ISLAMIC BAKING VERSUS U.S. BANKING}

\begin{tabular}{|c|c|}
\hline Islamic Banking & U.S. Banking \\
\hline $\begin{array}{l}\text { Islamic financial system shares the risk of } \\
\text { investment that translates into sharing the risk of } \\
\text { ownership concurrently (Iqbal \& Molyneux, } \\
\text { 2016). } \\
\text { However, in Islamic banking money retains its } \\
\text { position at store value (Iqbal \& Molyneux, } \\
\text { 2016). }\end{array}$ & $\begin{array}{l}\text { In U.S. banking, money is treated as a } \\
\text { commodity that can be sold at a price higher } \\
\text { than its face value. } \\
\text { Using money as a commodity, the U.S. banking } \\
\text { system can lead to inflation. }\end{array}$ \\
\hline $\begin{array}{l}\text { Islamic financial institutions should not involve } \\
\text { any circumstances, an element or a transaction } \\
\text { based on interest (Chong \& Liu, 2009; Iqbal \& } \\
\text { Molyneux, 2016). } \\
\text { Islamic banking is based on real assets and } \\
\text { transactions that have a certain economic } \\
\text { purpose (Azmat, Skully, \& Brown, 2015). In } \\
\text { Islamic banking, profit is earned through the } \\
\text { trade of goods and services (Azmat, et al., } \\
2015 \text { ). } \\
\text { Islamic banking contributes to the development } \\
\text { of the economy by linking the sectors of the } \\
\text { economy to trade activities and thus creating a } \\
\text { link with the real assets as well (Chong \& Liu, } \\
\text { 2009; Iqbal \& Molyneux, 2016) }\end{array}$ & $\begin{array}{l}\text { In U.S. banking, interest is charged on the time } \\
\text { value of capital. } \\
\text { In U.S. banking, interest is charged even when } \\
\text { the party bears losses (Naser, et al., 1999). }\end{array}$ \\
\hline $\begin{array}{l}\text { Islamic financial system grants that fairness } \\
\text { should be guaranteed in the execution of the } \\
\text { agreements so that there are no uncertain terms } \\
\text { and conditions for every party involved (Naser, } \\
\text { Jamal, \& Al-Khatib, 1999). } \\
\text { In Islamic banking, the bank will share the } \\
\text { losses depending on the financial instrument } \\
\text { used (Chong \& Liu, 2009). } \\
\text { In Islamic banking, disbursing cash finances, } \\
\text { agreements regarding the exchange of goods } \\
\text { and services must be made and followed } \\
\text { (Chong \& Liu, 2009). }\end{array}$ & $\begin{array}{l}\text { In U.S. banking, no agreement is made to allow } \\
\text { for the exchange of services when dealing with } \\
\text { the disbursement of cash finance, working } \\
\text { capital finance or running finance. }\end{array}$ \\
\hline
\end{tabular}


Islamic banking is generally differentiated from conventional banking in the aspect of being based on a system of moral values and ethicality that derive from Islamic religion, enduring to the principles of Islamic law, which are the divine sanctions that serve as guides for all aspects of life and daily dealings. After the establishment of a first Islamic bank, the Islamic banking industry has witnessed a slow but continued expansion. In this regard, two different approaches have been followed:

1. Islamic banks and financial institutions were established in several parts of the world, including some non-Muslim countries. The number of such banks and financial institutions is now more than one hundred.

2. Attempts were initiated to convert the whole financial system to Islamic principles in some Muslim countries. These include Pakistan and Sudan.

Fundamentally, Islam Contract Law states that contracts must be free of uncertainty, also known as "the rule against gharar" (Abedifar, et al., 2015; Chong \& Liu, 2009; Coulson, 2017). The Banking Control Regulation defines penalties for banks in breach of the provisions of such laws, including cancellation of the license for continual breaches by the Ministry of Finance and National Economy subject to the approval of the Council of Ministers. Other penalties that can be imposed or ordered by SAMA (Saudi Arabian Monetary Authority) include:

a) Suspension or removal of any of the bank's staff who deliberately produced incorrect data or stated inaccurate information or events

b) Suspension or removal of any director or officer of the bank

c) Limiting or suspending the granting of credits or the acceptance of deposits

d) Fines and imprisonment

\section{KUWAIT BANKING SYSTEM}

In 2003, the Central Bank of Kuwait Law (Act No 32/1968) was amended to reflect the need to have clear legal differences between Islamic and traditional banking practices. This was done to maintain a balance between traditional and Islamic banks. On one side, Islamic banks have a Sharia Board to oversee religious aspects of each transaction. In comparison, their traditional banking counterparts do not face the same restrictions. Customers are attracted to the service quality and convenience that the westernized approach offers. However, religious leaders claim that the traditional banking method was sinful. The employees of these institutions were not considered "halal." The term "halal" refers to something that is permissible or lawful in traditional Islamic law. This complication causes a challenge for those individuals who prefer the modern banking approaches but conflict with their religious leaders' teachings.

The Islamic banking system is recognized as a major banking system in both western and eastern societies around the world. So a large number of Kuwaiti lenders are moving away from conventional banking into a booming market for Sharia-compliant financial products in the region. Recently, the Commercial Bank of Kuwait (CBK) exposed its plans to turn into a fully-fledged Islamic institution. The move by CBK will help Kuwait to strengthen its position as a provider of Sharia-compliant products and services. This move by CBK towards Islamic banking follows a broader regional global trend.

\section{CULTURAL DIFFERENCES}

Geert Hofstede $(1984,2003)$ studied how different cultures functioned differently. In the early 1980s, he surveyed 116,000 IBM employees from across the globe. His original work examined cross cultural differences, power distance (PDI), individual versus collectivism (INV), and long-term versus short-term orientation (LTO). He has since added additional dimensions, which can be viewed on his website (Hofstede, 2011). He defines the dimensions as follows:

1. Power Distance (PDI) - measures the extent to which less powerful members of organizations accept an unequal distribution of power, which in turn leads to hierarchical vs. egalitarian forms of human behavior. 
2. Individualism (IDV) - measures the degree to which people in a country prefer to act as individuals or members of a group, which in turn leads to group-oriented vs. individualistic forms of behavior.

3. Long-Term Orientation (LTO) - measures individual's devotion to work ethic and their respect for tradition.

As one might expect, the culture of Kuwait aligns more similarly to Saudi Arabia than it does the United States in many measures. (See table 2: Hofstede Dimensions).

TABLE 2

HOFSTEDE CULTURAL DIMENSIONS

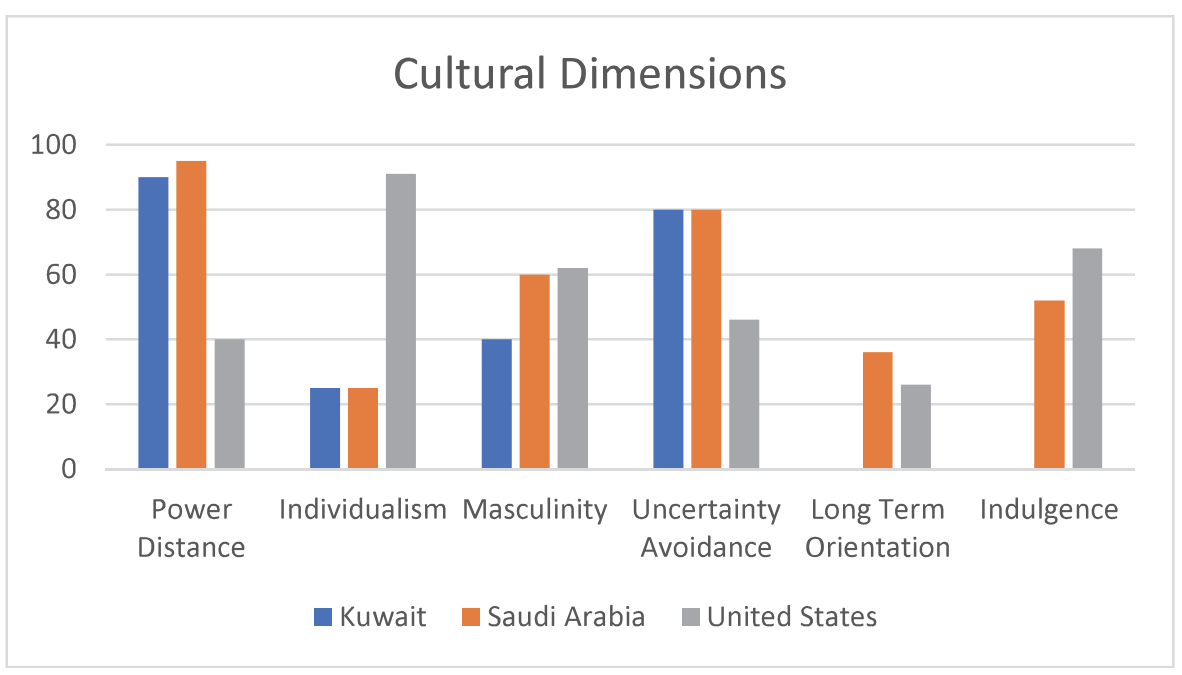

As indicated by table 2, Kuwait and Saudi Arabia share high power distance. This exemplfies a cultural attitude towards inequalities. Every person has a place and needs no futher justificaiton. Powerful members tell suborinates what ot do with little or no questioning of authority. Similarly, both countries score low on the individuaism scale, another stark contrast to the United States. The low score for the Middle Eastern countries indicates a high degree of interdependance, or relationships. People belong to a group who will take care of them in exchange for loyalty. Uncertainty avoidace is a category where Kuwait and Saudi Arabia diverge from the United States. Kuwait scores 80 in this dimension, thus indicating a preference for avoiding uncertainty. Countries like this often maintain rigid codes of belief and behavior, and are less tolerant of unorthadox behaviors and ideas. There becomes a need for rules. The main area that Kuwait differs from the other two countries is the Masculinity/Femininity dimension. Kuwait is much lower than the other two, meaning people value equality, solidarity, and quality in their working lives. Conflicts are handled with compromise and negotiation. Uncertainty Avoidance, in essence, is the cultures willingess to accept risk. As table 2 indicates, the United States and the traditional Islamic Banking countries differ quite signiicantly.

\section{RISK TAKING}

Risk return relationship has been studied extensively. It was Knight who made a distinction between risk and uncertainty (Knight, 1921). Knight argued that when a probability distribution of an event can be established, it becomes risk; otherwise, it is uncertainty (Knight, 1921). Later, some researchers argue that in most business literature, risk and uncertainty is used interchangeably (R.A. Bettis, 1982; Richard A. Bettis, 1983; Richard. A. Bettis \& Hitt, 1995). In business strategy research, the notion of risk is usually attributed to downside unpredictability of business operations, like loss of revenue, increase of costs, decrease of profits, loss of market share and so on (R.A. Bettis, 1982; Richard A. Bettis, 1983; Richard. 
A. Bettis \& Hitt, 1995). Sometimes uncertainty refers to the perception of environmental unpredictability and different business contingencies (DeSarbo, Anthony Di Benedetto, Song, \& Sinha, 2005; Miles \& Snow, 1992).

Capital Asset Pricing Model (CAPM) linked pricing mechanism of systematic and unsystematic risks that constitute firms total risk (Linter, 1965; Sharpe, 1964). While unsystematic or firm specific risk can be eliminated through diversification tools, systematic risk cannot be eliminated (Chatterjee, Lubatkin, \& Schulze, 1999; Eugene F. Fama \& French, 1996a, 1996b). The specific company risk is measured using a beta tool, which shows the relationship of a company stock to the market index, and calculating beta is one of the key underlying concepts of CAPM (Chatterjee, et al., 1999; Eugene F. Fama \& French, 1996a, 1996b). Three categories of measures based on downside were introduced by Miller and Reuer (1996) and included (1) lower partial moments, (2) beta from a downside version of the CAPM and (3) downside measures of stock analysis's earnings forecasts. Few studies tried to apply concepts of CAPM to Islamic equity markets. The current tendency in Islamic banking is to move to global markets and expand from purely an Islamic banking industry to wider areas of investment tools, and this tendency made Islamic banking one of the fastest growing capital markets in the world (Dewandaru, Bacha, Masih, \& Masih, 2015). Comparative analysis found no statistical significance between beta coefficients in traditional Western markets and Islamic markets (Dewandaru, et al., 2015), and even exceptions to the statistical significance show lower risk for the same level of returns for Islamic indices at the higher time scales (Dewandaru, et al., 2015). The differentiating feature of Islamic banking is a profit or loss sharing paradigm (PLS), that in the study of Malaysian banks showed that an increase in growth of Islamic banking activity is linked to Islamic resurgence around the world and not PLS phenomena (Chong \& Liu, 2009). Profitability of Islamic banks related positively to increases in capital and negatively to loan rations, and higher ratios of equity to total assets lead to higher profit margins (Hassan \& Bashir, 2003; Yudistira, 2003). These findings are consistent with past research and suggest that high capital ratios play a smaller role in explaining the performance of most Islamic banks (Ahmad \& Haron, 1998; Ariff, 1988; Gerrard \& Barton Cunningham, 1997). Generally speaking, Islamic banks have a portfolio that consists of a higher percentage of short term trade financing, which means most loans are low risk and have smaller contributions of the bank's overall profits (Azmat, et al., 2015; Coulson, 2017; Hassan \& Bashir, 2003). Regulatory tax was shown to be linked to Islamic banks' performance while reserve requirements had a weak impact on profitability (Hassan \& Bashir, 2003). A positive macroeconomic environment and high growth rate of GDP enhanced profitability of Islamic banks, while per capita GDP and inflation rate had no statistically significant effect on performance (Hassan \& Bashir, 2003). The size of a banking system had a negative impact on the profitability of Islamic banks (Hassan \& Bashir, 2003).

Company level risk has multiple dimensions, reflecting the various interests of the coalition members and stakeholders (Cyert \& March, 1963; R. Freeman, 1984; R. E. Freeman, Harrison, Wicks, Parmar, \& De Colle, 2010). In general, there is an agreement that risk influences business performance (Bromiley, Miller, \& Rau, 2001; K. Miller \& Leiblein, 1996; Wiseman \& Bromiley, 1991).

A negative relationship between risk and return is rather an exception but has been documented in several studies (Bowman, 1980; Kim, Hwang, \& Burgers, 1993), with the main explanation being that more successful companies have more slack in their resources and can afford taking lower risk levels. The majority of studies have robust conclusions that risk and return has positive correlations, meaning higher returns are associated with higher risk levels and vice versa (Banz, 1981; Richard A Bettis \& Hall, 1982; Cool, Dierickx, \& Jemison, 1989; Eugene F Fama \& MacBeth, 1973; Fiegenbaum, 1990; Ghysels, SantaClara, \& Valkanov, 2005). Therefore, we hypothesize that:

H1: Kuwait Banks with higher risk taking will experience higher profitability.

H2: Larger Kuwait Banks will experience higher profitability. 


\section{DATA ANALYSIS}

To test the hypothesis, we collected data on all existing Kuwaiti banks following the passage of Central Bank of Kuwait Law (Act No 32/1968). In total, we had at least ten years of data for nine separate Kuwait banks. We omitted any years that didn't have complete data for a particular bank. Interestingly, as the industry is becoming more westernized, all but one institution provides their annual reports in English. For Boubyan Bank, the Arabic annual report was translated by one of the co-authors. Data was collected on size (assets), profit (net income), risk (risk-based capital ratio), and profitability (ROA). The sample banks included: Ahli United Bank, Al Ahli Bank of Kuwait, Bank of Bahrain and Kuwait, Boubyan Bank, Burgan Bank, Commercial Bank, Gulf Bank, Kuwait Financial House, and National Bank of Kuwait. Analysis of banks founded after 2004 began after their founding date. Data was analyzed using multiple regression in SPSS, a statistical program.

\section{DISCUSSION}

Risk taking was found to be a significant predictor of bank profitability in the Kuwaiti Banking Industry in support of hypothesis 1 . In fact, nearly $10 \%$ of variation of profitability in Kuwait Banks can be attributed to risk taking alone. We also expected bank size (hypothesis 2) to play a significant role in the overall profitability but concluded that was not the case. Government regulation (Nair, Trendowski, \& Judge, 2009) can have a major impact on bank performance. When a particular industry faces significant change, older banks may face the liability of aging (see Ranger-Moore 1997). Many of the legitimacy benefits from being a long standing, powerful member are diminished when the environment shifts. The autonomy allowed by the passage of (Central Bank of Kuwait Law (Act No 32/1968), in 2003, provided Kuwait banks an opportunity to be risk seekers, like their western counterparts. This flux in the market reduced the institutional benefits once held by the large, powerful Kuwaiti Banking institution. Unlike the US market, that saw risk taking lead to higher failure rates following the 2008 financial crisis (Trendowski \& Rustambekov, 2017), the Kuwaiti market did not face the same negative side of the risk paradox. Islamic Banking practices are still a strong influence in many Kuwaiti Banks. Though some institutions have increased risk taking, and enjoyed higher returns, they still maintain presence of Islamic Banking. Additionally, institutional changes develop over time, so it is possible that different institutions will evolve differently with the new freedom. Some may become increasingly westernized over time, while others will remain closely associated with Islamic Banking.

\section{REFERENCES}

Abdul-Muhmin, A. G., \& Umar, Y. A. (2007). Credit card ownership and usage behaviour in Saudi Arabia: The impact of demographics and attitudes toward debt. Journal of Financial Services Marketing, 12(3), 219-234.

Abedifar, P., Ebrahim, S. M., Molyneux, P., \& Tarazi, A. (2015). Islamic banking and finance: recent empirical literature and directions for future research. Journal of Economic Surveys, 29(4), 637670 .

Ahmad, N. H., \& Haron, S. (1998). The existence of conventional banking profitability theories in the Islamic banking system. Analisis, 5(1\&2), 89-97.

Al-Malkawi, H.-A. N., Mansumitrchai, S., \& Al-Habib, M. (2016). Online banking in an emerging market: evidence from Saudi Arabia. International Journal of Electronic Finance, 9(1), 1-17.

Ali, M., Raza, S. A., \& Puah, C.-H. (2017). Factors affecting to select Islamic credit cards in Pakistan: the TRA model. Journal of Islamic Marketing, 8(3), 330-344.

AlKulaib, Y. A., Al-Jassar, S. A., \& Al-Saad, K. (2016). Theory And Practice In Capital Budgeting: Evidence From Kuwait. Journal of Applied Business Research, 32(4), 1273.

Ariff, M. (1988). Islamic banking. Asian-Pacific Economic Literature, 2(2), 48-64. 
Azmat, S., Skully, M., \& Brown, K. (2015). Can Islamic banking ever become Islamic? Pacific-Basin Finance Journal, 34, 253-272.

Banz, R. W. (1981). The relationship between return and market value of common stocks. Journal of Financial Economics, 9(1), 3-18.

Beck, T., Demirgüç-Kunt, A., \& Merrouche, O. (2013). Islamic vs. conventional banking: Business model, efficiency and stability. Journal of Banking \& Finance, 37(2), 433-447.

Bettis, R. A. (1982). Risk considerations in modeling corporate strategy.

Bettis, R. A. (1983). Modern Financial Theory, Corporate Strategy and Public Policy: Three Conundrums. The Academy of Management Review, 8(3), 406-415.

Bettis, R. A., \& Hall, W. K. (1982). Diversification strategy, accounting determined risk, and accounting determined return. Academy of Management Journal, 25(2), 254-264.

Bettis, R. A., \& Hitt, M. A. (1995). The new competitive landscape. Strategic Management Journal, 16(S1), 7-19.

Bowman, E. H. (1980). A risk/return paradox for strategic management. Sloan management review, 21(3), 17-31.

Bromiley, P., Miller, K. D., \& Rau, D. (2001). Risk in strategic management research. The Blackwell handbook of strategic management, 259-288.

Chatterjee, S., Lubatkin, M. H., \& Schulze, W. S. (1999). Toward a Strategic Theory of Risk Premium: Moving beyond Capm. The Academy of Management Review, 24(3), 556-567.

Chong, B. S., \& Liu, M.-H. (2009). Islamic banking: interest-free or interest-based? Pacific-Basin Finance Journal, 17(1), 125-144.

Cool, K., Dierickx, I., \& Jemison, D. (1989). Business strategy, market structure and risk-return relationships: A structural approach. Strategic Management Journal, 10(6), 507-522.

Cooper, R., \& Jarre, A. (2017). An agent-based model of the South African offshore hake trawl industry: part II drivers and trade-offs in profit and risk. Ecological Economics, 142, 257-267.

Coulson, N. (2017). A history of Islamic law: Routledge.

Cyert, R., \& March, J. (1963). A behavioral theory of the firm. Englewood Cliffs, NJ: PrenticeHall.

DeSarbo, W. S., Anthony Di Benedetto, C., Song, M., \& Sinha, I. (2005). Revisiting the Miles and Snow strategic framework: uncovering interrelationships between strategic types, capabilities, environmental uncertainty, and firm performance. Strategic Management Journal, 26(1), 47-74.

Dewandaru, G., Bacha, O. I., Masih, A. M. M., \& Masih, R. (2015). Risk-return characteristics of Islamic equity indices: Multi-timescales analysis. Journal of Multinational Financial Management, 29, 115-138.

Fama, E. F., \& French, K. R. (1996a). The CAPM is Wanted, Dead or Alive. The Journal of Finance, 51(5), 1947-1958.

Fama, E. F., \& French, K. R. (1996b). Multifactor Explanations of Asset Pricing Anomalies. The Journal of Finance, 51(1), 55-84.

Fama, E. F., \& MacBeth, J. D. (1973). Risk, return, and equilibrium: Empirical tests. Journal of political economy, 81(3), 607-636.

Fiegenbaum, A. (1990). Prospect theory and the risk-return association: An empirical examination in 85 industries. Journal of Economic Behavior \& Organization, 14(2), 187-203.

Freeman, R. (1984). Strategic management: A stakeholder theory. Journal of Management Studies, 39(1), $1-21$.

Freeman, R. E., Harrison, J. S., Wicks, A. C., Parmar, B. L., \& De Colle, S. (2010). Stakeholder theory: The state of the art: Cambridge University Press Cambridge.

Gerrard, P., \& Barton Cunningham, J. (1997). Islamic banking: a study in Singapore. International journal of bank marketing, 15(6), 204-216.

Ghysels, E., Santa-Clara, P., \& Valkanov, R. (2005). There is a risk-return trade-off after all. Journal of Financial Economics, 76(3), 509-548.

Hassan, M. K., \& Bashir, A.-H. M. (2003). Determinants of Islamic banking profitability. Paper presented at the 10th ERF annual conference, Morocco. 
Hofstede, G. (1984). The Cultural Relativity of the Quality of Life Concept. The Academy of Management Review, 9(3), 389-398.

Hofstede, G. (2003). Culture's consequences: Comparing values, behaviors, institutions and organizations across nations: Sage publications.

Hofstede, G. (2011). Dimensionalizing cultures: The Hofstede model in context. Online readings in psychology and culture, 2(1), 8.

Iqbal, M., \& Molyneux, P. (2016). Thirty years of Islamic banking: History, performance and prospects: Springer.

Kim, W. C., Hwang, P., \& Burgers, W. P. (1993). Multinationals' diversification and the risk-return tradeoff. Strategic Management Journal, 14(4), 275-286.

Knight, F. (1921). Risk, Uncertainty, and Profit. Boston, MA: Hart, Schaffner \& Marx.

Kuran, T. (2012). The long divergence: How Islamic law held back the Middle East: Princeton University Press.

Linter, S. (1965). Predicting the bear stock market: Macroeconomic variables as leading indicators. Journal of Banking \& Finance, 33, 211-223.

Makki, E., \& Chang, L.-C. (2015). E-commerce acceptance and implementation in saudi arabia: previous, current and future factors. The International Journal of Management Research and Business Strategy, 4(3), 29-44.

Metcalfe, B. D. (2006). Exploring cultural dimensions of gender and management in the Middle East. Thunderbird International Business Review, 48(1), 93-107.

Metcalfe, B. D. (2007). Gender and human resource management in the Middle East. The International Journal of Human Resource Management, 18(1), 54-74.

Miles, R. E., \& Snow, C. C. (1992). Causes of failure in network organizations. California management review, 34(4), 53-72.

Miller, K., \& Leiblein, M. (1996). Corporate risk-return relations: Returns variability versus downside risk. Academy of Management Journal, 39(1), 91-122.

Miller, K. D., \& Reuer, J. J. (1996). Measuring organizational downside risk. Strategic Management Journal, 17(9), 671-691.

Nair, A., Trendowski, J., \& Judge, W. (2009). Re-visiting Edith Penrose’s (1959)‘'Theory of the Growth of the Firm'.

Naser, K., Jamal, A., \& Al-Khatib, K. (1999). Islamic banking: a study of customer satisfaction and preferences in Jordan. International journal of bank marketing, 17(3), 135-151.

Ranger-Moore, J. (1997). Bigger may be better, but is older wiser? Organizational age and size in the New York life insurance industry. American Sociological Review, 903-920.

Saeed, A. (1996). Islamic banking and interest: A study of the prohibition of riba and its contemporary interpretation (Vol. 2): Brill.

Schotter, A., \& Abdelzaher, D. (2013). The boundary spanning effects of the Muslim diaspora on the internationalization processes of firms from organization of Islamic conference countries. Journal of International Management, 19(1), 82-98.

Sharpe, W. F. (1964). Capital Asset Prices: A Theory of Market Equilibrium under Conditions of Risk. The Journal of Finance, 19(3), 425-442.

Trendowski, J., \& Rustambekov, E. (2017). Risk Taking and Bank Failure Before and After the Onset of the Financial Crisis-A Decade in Review. The Journal of Applied Business and Economics, 19(8), 79-93.

Velez-Calle, A., Robledo-Ardila, C., \& Rodriguez-Rios, J. D. (2015). On the influence of interpersonal relations on business practices in Latin America: A comparison with the Chinese guanxi and the Arab Wasta. Thunderbird International Business Review, 57(4), 281-293.

Wiseman, R. M., \& Bromiley, P. (1991). Risk-return associations: Paradox or artifact? An empirically tested explanation. Strategic Management Journal, 12(3), 231-241.

Yudistira, D. (2003). Efficiency in Islamic banking: An empirical analysis of 18 banks. Islamic financial architecture, 479.

94 Journal of Applied Business and Economics Vol. 20(9) 2018 